\title{
Colloquium on diatom-copepod interactions
}

\author{
G. A. Paffenhöfer ${ }^{1, *,+, \downarrow}$, A. Ianora $a^{2+,+}$, A. Miralto ${ }^{2,+}$, J. T. Turner ${ }^{3, \bullet}$, G. S. Kleppel ${ }^{4, \bullet}$, \\ M. Ribera d'Alcalà ${ }^{2, \bullet}$, R. Casotti ${ }^{2, \bullet}$, G. S. Caldwell ${ }^{5, \bullet}$, G. Pohnert ${ }^{6, \bullet}$, A. Fontana ${ }^{7, \bullet}$,

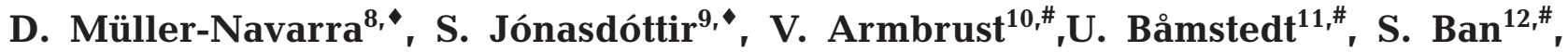 \\ M. G. Bentley,"\#, M. Boersma ${ }^{13, \#, \text { M. Bundy }}{ }^{14, \#}$, I. Buttino ${ }^{2, \#}$, A. Calbet ${ }^{15, \#}$, F. Carlotti ${ }^{16, \#,}$, \\ Y. Carotenuto ${ }^{2, \#}$, G. d'Ippolito ${ }^{2, \#}$, B. Frost ${ }^{10, \#}$, C. Guisande ${ }^{17, \#, \text { W. Lampert }}{ }^{18, \# \text {, }}$ \\ R. F. Lee ${ }^{1, \#}$, S. Mazza ${ }^{2, \#}$, M. G. Mazzocchi ${ }^{2, \#}$, J. C. Nejstgaard ${ }^{11, \#}$, S. A. Poulet ${ }^{19, \#,}$ \\ G. Romano ${ }^{2, \#}$, V. Smetacek ${ }^{20, \#}$, S. Uye ${ }^{21, \#}$, S. Wakeham ${ }^{1, \#, ~ S . ~ W a t s o n ~}{ }^{22, \#, ~ T . ~ W i c h a r d ~}{ }^{6, \#}$
}

\begin{abstract}
${ }^{1}$ Skidaway Institute of Oceanography, Savannah, Georgia 31411, USA; ${ }^{2}$ Stazione Zoologica Anton Dohrn, 80121 Napoli, Italy; ${ }^{3}$ Biology Department, University of Massachusetts Dartmouth, North Dartmouth, Massachusetts 02747, USA; ${ }^{4}$ Department of Biological Sciences, University at Albany, State University of New York, Albany, New York 12222, USA; ${ }^{5}$ Marine Science and Technology, University of Newcastle upon Tyne, Newcastle upon Tyne NE1 7 RU, UK; ${ }^{6}$ Max-Planck-Institut für Chemische Ökologie, 07745 Jena, Germany; ${ }^{7}$ Istituto per la Chimica Biomolecolare del CNR, 80121 Napoli, Italy; ${ }^{8}$ Institut für Hydrobiologie und Fischereiwissenschaft, 22767 Hamburg, Germany; ${ }^{9}$ Department of Marine Ecology and Aquaculture, Danish Institute for Fisheries Research, 2920 Charlottenlund, Denmark; ${ }^{10}$ School of Oceanography, University of Washington, Seattle, Washington 98195-7940, USA; ${ }^{11}$ Department of Fisheries and Marine Biology, University of Bergen, 5020 Bergen, Norway; ${ }^{12}$ University of Shiga Prefecture, Hikone, Tokyo 164, Japan; ${ }^{13}$ AWI-Biologische Anstalt Helgoland, 27498 Helgoland, Germany; ${ }^{14}$ Academy of Natural Sciences Estuarine Research Center, St. Leonard, Maryland 20685, USA; ${ }^{15}$ Institut de Ciències del Mar - CMIMA (CSIC), 08003 Barcelona, Spain; ${ }^{16}$ Station Marine d'Arcachon, CNRS, Université de Bordeaux, 33120 Arcachon, France; ${ }^{17}$ Facultad de Ciencias, Universidad de Vigo, 36200 Vigo, Spain; ${ }^{18}$ Max-Planck-Institut für Limnologie, 24302 Plön, Germany; ${ }^{19}$ Station Biologique, CNRS, 29680 Roscoff, France; ${ }^{20}$ Alfred-Wegener-Institut für Polar- und Meeresforschung, 27515 Bremerhaven, Germany; ${ }^{21}$ Hiroshima University, Higashi-Hiroshima 739-8528, Japan; ${ }^{22}$ Environment Canada and University of Calgary, Alberta T2N 1N4, Canada
\end{abstract}

\begin{abstract}
From 3 to 6 November 2002, a colloquium was convened at the Benthos Laboratory of the Stazione Zoologica Anton Dohrn on Ischia, Italy, with the goal of evaluating the present status of the effects of diatoms on their main consumers, planktonic copepods, and to develop future research strategies to enhance our understanding of such interactions. These included (1) toxic effects of diatom metabolites on copepods, particularly reproduction, and (2) nutritional effects of diatoms on juvenile to adult copepods. Key issues involved in the impact of diatoms on the dynamics of natural plankton communities in situ were also addressed. During the plenary session, the most recent advances on this topic were presented. The plenary session was followed by 3 working groups on (1) production of aldehydes by phytoplankton, (2) toxic and nutritional effects of diatoms on zooplankton, and (3) the chemistry of diatom defense, as well as of their nutritional quality. These working groups focused on suggesting future research needs for the different topics. As a result, several recommendations were outlined, including experimental studies. It became evident that interdisciplinary efforts are needed, involving chemists, oceanographers and experimentalists, since many of the biological observations under controlled conditions and in situ require an integrated approach, including chemical causation. Extensive field observations based on common protocols are also recommended for investigation of the intrinsic variability of such effects and their environmental controls. Laboratory experiments are seen to be essential for the full understanding of environmentally occurring processes.
\end{abstract}

KEY WORDS: Diatoms $\cdot$ Copepods $\cdot$ Toxicity $\cdot$ Nutrition 


\section{INTRODUCTION}

\section{Main contributors: J. T. Turner and G. S. Kleppel}

Phytoplankton blooms have been a major issue in marine ecology for more than a century (Mills 1989 and references therein). Diatoms are often major components of these blooms, and have long been considered as principal components of planktonic copepod diets (Dakin 1908, Marshall 1924, 1973, Clarke 1939, Mauchline 1998), enhancing copepod fecundity and thereby supporting major fisheries (Ryther 1969, Greve \& Parsons 1977, Cushing 1989).

The diatom-copepod link was fully accepted in biological and fishery oceanography by the midtwentieth century. However, substantial data refuting the diatom $\rightarrow$ copepod $\rightarrow$ fish model began to emerge in the late 1980's and continued throughout the 1990's. Increased appreciation for the 'microbial loop' (Azam et al. 1983) and the importance of heterotrophic protists in grazing the dominant picoplanktonic phytoplankton somewhat diminished the importance of copepods as grazers of diatoms. Substantial, or even preferential, predation of copepods on heterotrophic protists and dinoflagellates (Sherr et al. 1986, Stoecker \& Capuzzo 1990) seemed to reduce the importance of diatoms as copepod food. In fact, some copepods previously regarded as 'herbivores' have been shown to readily ingest heterotrophic protists and sustain fecundity on these food taxa (Ohman \& Runge 1994), and such copepod production can contribute to larval fish recruitment during periods of low phytoplankton chlorophyll (Runge \& de Lafontaine 1996). Additionally, copepod egg production was observed to be more closely correlated with heterotrophic protist and dinoflagellate biomass than with that of diatoms (Kleppel et al. 1991, Ohman \& Runge 1994). Thus, by the 1990's, it was clear that the diatom-copepod trophic linkage was only part of a complicated planktonic food web, rather than a predominant food chain (reviewed by Kleppel 1993, Turner \& Roff 1993, Verity \& Paffenhöfer 1996).

In addition to the aforementioned studies, other information began to accumulate in the 1990's that questioned the beneficial role of diatoms as copepod food. Briefly, a body of evidence (reviewed by Paffenhöfer 2002, Ianora et al. 2003) indicated that ingestion of some diatom species by females of some calanoid species could decrease their reproductive success due to the presence of teratogenic, or reproductioninhibitory chemicals in these diets. Unsaturated aldehydes (the term 'aldehyde(s)' is used in the text as an abbreviation to cover biologically active $\alpha, \beta, \gamma, \delta$ - or $\alpha, \beta$ unsaturated aldehydes) in some diatom species inhibited mitosis in developing copepod eggs and sea urchin embryos (Miralto et al. 1999), and induced abnormal development of copepod nauplii in both the laboratory (Poulet et al. 1995, Carotenuto et al. 2002) and in the sea during periods of diatom abundance (Laabir et al. 1995a, 1998, Miralto et al. 2003, Ianora et al. 2004). Diets consisting of several species of diatoms have been shown to reduce egg viability in several species of copepods (Ianora et al. 1995, 1996, Ban et al. 1997, Lee et al. 1999, Starr et al. 1999, Lacoste et al. 2001). The reduction of egg hatching success is proportional to the length of exposure of egg-producing females to diatom diets (Laabir et al. 1995b, Turner et al. 2001), and to diatom concentrations (Chaudron et al. 1996).

As an alternative, some authors have argued that poor copepod egg production and egg viability result from nutritional inadequacies rather than teratogens in diatom diets of egg-producing female copepods (Jónasdóttir et al. 1998). Numerous correlations have been found between copepod fecundity and various elemental and biochemical components of maternal diets such as carbon, nitrogen, protein, carbohydrate, amino acid, and fatty acid content (Jónasdóttir 1994, Pond et al. 1996, Kleppel et al. 1998a,b, Koski et al. 1998). Schmidt \& Jónasdóttir (1997) showed that copepod egg production increased when additional taxa were added to unialgal diets of nutritionally poor cyanobacteria. Copepod egg-hatching success was correlated to size and biochemical content (protein, carbohydrate, lipid) of eggs, and these parameters were correlated to biochemical compounds in natural food assemblages (Guisande \& Harris 1995). Both copepod egg production and egg hatching have been correlated to dietary levels of fatty acids or amino acids in laboratory-cultured (Jónasdóttir \& Kiørboe 1996, Guisande et al. 2000) and natural (Pond et al. 1996) diets. Other studies have revealed variable rates of copepod egg production on diets of natural phytoplankton dominated by various taxa (Tang et al. 1998, Irigoien et al. 2000a), with high variability in the effects on fecundity when diatoms were dominant (Irigoien et al. 2000b).

To consider the controversial issue regarding the relationship between diatoms and copepods, a meeting was convened at the Stazione Zoologica Anton Dohrn Benthos Laboratory, Ischia, Italy, from 3 to 6 November 2002. The goal of this meeting was to evaluate the present status of diatom-copepod interaction research, including unpublished results, and consider means by which to explore the effects of nutritional quality and the influence of secondary metabolites on the relationships between diatoms and copepods. Thirty-seven scientists from 10 countries participated. A consensus emerged from the meeting that a research agenda ought to be developed, aiming towards a comprehensive understanding of one of 
the most fundamental and long-recognized interactions in the sea, which is that between diatoms and copepods.

In the following sections we will first present reports from 3 working groups: The first group, concentrating on phytoplankton, largely focused on aldehyde production and the mechanisms leading to such production. The second, concentrating on zooplankton, developed questions about how diatoms affect copepod reproduction and other population dynamics variables. The third group, concentrating on chemistry, had 2 points of interest, i.e. the chemistry of diatom defense and the nutritional chemistry of diatoms. In the last section we present considerations for future research, followed by concluding remarks.

\section{PRODUCTION OF ALDEHYDES BY PHYTOPLANKTON}

\section{Main contributors: M. Ribera d'Alcalà and R. Casotti}

This section originates from a working group evaluating aldehyde production, and possible mechanisms initiating or modulating the formation of aldehydes from phytoplankton. The production of defense molecules against predation are widely known for both terrestrial (Rosenthal \& Berenbaum 1991) and marine (McClintock \& Baker 2001) higher plants. Much less is known about the production of these molecules in marine phytoplankton. Unsaturated aldehyde production has been shown to vary among different phytoplankton species, different genotypes of the same morphological species and different sites. Also, diatom aldehydes have been shown to differ in their toxicity, and those with an $\alpha, \beta$-unsaturation and longer chain length are more toxic to animals than others (Adolph et al. 2003, Romano et al. 2003). However, it is not yet clear which phytoplankton populations produce aldehydes in nature, because relatively few species have been biochemically analyzed to date. Many of these are, indeed, species that form blooms, which reinforces the idea of a positive feedback between the production of aldehydes and increased diatom cell numbers at sea. On the other hand, species that do not form blooms have also been shown to produce the same or similar aldehydes, suggesting that chemical defense, per se, is not a sufficient requisite for increased population growth. Since all aldehydes require multi-step enzymatic catalysis, important questions arise about the genetic control of such processes. Such questions can be addressed in the near future using molecular tools, made possible by the recent sequencing and annotation of the marine diatom Thalassiosira pseudonana genome (Armbrust et al. 2004).
If the production of unsaturated aldehydes depends on a cell-controlled activation mechanism, their release should depend on a trigger. This trigger could be external (wound induction, presence of grazers, nutrient concentration, nutritional differences) or endogenous (growth stage, biochemical composition). Once chemical analytical methods advance, studies of the physiological control of aldehyde production at the cellular scale should be initiated, in order to dissect the endogenous mechanisms of aldehyde production by diatoms. Toxin production in phytoplankton is often related to different phases of the growth cycle (Imada et al. 1991, Schmidt \& Hansen 2001), or even to cellcycle phases (Bates et al. 1993, Bolch et al. 2002). It will have to be shown whether aldehyde production is higher in senescent cells or exponentially growing cells. The former would imply that grazers feeding at the end of a bloom are more affected than early-bloom grazers, while the latter would imply the opposite. Both scenarios would have strong implications for recruitment and trophic interactions at sea.

External factors triggering or modulating aldehyde production also need to be investigated, and light and nutrients are potentially important factors to consider. In freshwater chrysophytes producing the same aldehydes, physiological conditions, and light and nutrient availability, strongly modulate their production, which has strong implications for the phytoplankton community composition (Watson \& Satchwill 2003). If similar results are obtained for marine bloom-forming species, this may represent a strong determinant for bloom dynamics. For example, the high-light conditions that diatoms experience when trapped in the surface layers of the water column as a consequence of stratification may have an effect on such reactive molecules. UV activation or modulation of toxicity has, in fact, also been observed for similar compounds (Wiegman et al. 2002).

If the production of such compounds is rewarded by a higher survival rate of the clones, the energy investment must be low; otherwise other phytoplankters would outcompete the producers due to reduced grazing pressure (Yoshida et al. 2003). Chemical defenses may also be effective against other competing autotrophs. For example, Casotti et al. (2001) suggested that diatom-derived aldehydes have an allelochemical function, since they arrest the proliferation of other diatom cells. If aldehyde production is related to the peak phase of a bloom, then aldehydes may be a control mechanism to prolong algal survival when nutrients become limiting. Such an altruistic behavior may be mediated by active mechanisms at the cellular level, such as programmed cell death (i.e. apoptosis), as has been demonstrated in in vitro experiments on different animal and plant models (Casotti et al. 2001, 
2005, Romano et al. 2003). The release of aldehydes into the seawater in quantities that inhibit growth of competitors appears to be unrealistic (Pohnert 2000), but a quantitative assessment of aldehyde production during bloom conditions is still lacking. On the other hand, unsaturated aldehydes are produced by other algal groups in freshwater environments, in such high quantities as to cause serious socio-economic problems (Watson 2003). Unsaturated aldehyde production appears to be regulated by algal physiology, and therefore a possible role of these compounds as semiochemicals (i.e. pheromones, kairomones and allelogens) in freshwater habitats has been advanced (Watson \& Satchwill 2003). Also in the ocean, there is evidence for the presence of secondary microalgal metabolites with a signaling function (Wolfe et al. 1997), and the question is whether diatom-produced aldehydes may also have such a role.

Diatoms, as a group, are major contributors to carbon fixation in the ocean (Nelson et al. 1995), and a significant fraction of diatom biomass is effectively transferred through the marine food web. Pathways therefore exist which allow diatom grazers to safely grow, reproduce and transfer their carbon to their consumers. This may be based upon avoidance or limited intake of toxic species, or on resistance mechanisms of copepod species. Unicellular grazers might be unaffected by diatom-derived aldehydes, or could even neutralize their effects. Such grazers have long been considered to be more effective than copepods in consuming phytoplankton (e.g. Frost 1987), and a recent study supports that view (Calbet \& Landry 2004).

A thorough analysis of overlooked defense mechanisms will improve our understanding of the functioning of food webs and, thereby, of carbon drawdown by the ocean and the possible changes due to community shifts in the context of global change. It will also allow a better understanding of the impact of the diatom-copepod interactions on marine resources (fishery) and on the life strategies of pelagic and benthic organisms (marine biodiversity).

\section{TOXIC AND NUTRITIONAL EFFECTS OF DIATOMS ON ZOOPLANKTON}

\section{Main contributors: G. S. Caldwell and J. T. Turner}

This section originates from a working group which mainly focused on formulating questions about the ways and means by which diatoms affect copepod reproduction, and other population dynamics variables. The general mechanisms considered were toxicity and nutritional inadequacy. Although some results point to the second issue, the information available on the nutritional value of diatoms in situ is still scarce. It was emphasized that copepod species and also diatom species differ in their physiology, and that we possess hardly any knowledge as to how the ingestion of different diatom species would affect different copepod species, with a few published exceptions. The evidence that we have of a copepod species' feeding behavior in diatom blooms (e.g. Fessenden \& Cowles 1994) is limited, because such blooms and associated particle qualities can vary widely in their composition, leaving room for a range of behavioral responses of the different copepod species. Various aspects of the known effects of diatoms on copepod reproduction and nutrition are presented in earlier and following sections. Here we limit the presentation to general questions and ideas concerning diatom-copepod interaction research, covering field and experimental observations.

How often are diatom toxicity and/or nutritional inadequacy associated with diatom blooms? To answer this question the quantifications needed over time would have to include copepod ingestion rates of the different bloom particles, subsequent egg production and hatching, and naupliar and copepodid development and mortality (post-embryonic fitness). Also, a thorough analysis of phytoplankton composition and abundance, and the phytoplankton species' chemical composition (see 'Chemistry of diatom defense' and 'Nutritional chemistry of diatoms') is needed. Answering the above-mentioned question would require oceanographic observations, as well as specific laboratory experiments simulating field conditions as closely as possible. Observations of Ban et al. (2000) demonstrated clear negative effects of diatom blooms, as reflected by the asymmetry of nauplii which had hatched under the bloom conditions. The field studies ought to be designed to understand the ecological significance of toxic molecules for natural copepod populations. Again, it is essential to distinguish between the effects of toxicity and nutritional value.

Following this, are different species of calanoid copepods, which are the main copepod consumers of diatoms, with different feeding strategies similarly affected by the same diatom conditions? Here, the possibility of detoxification should be considered. While Miralto et al. (1999) speculated as to the apparent lack of detoxification systems in copepods, Ianora et al. (2003) showed that the same diatom species could induce different effects in different copepod species. Benthic invertebrates have revealed pronounced species-specific variability in the sensitivity of their embryos to aldehyde toxicity (Caldwell et al. 2002). No inhibitory effects on reproductive and population growth parameters were observed following ingestion of the benthic diatom Nitzschia closterium by the 
harpacticoid copepod Tisbe biminiensis (Pinto et al. 2001). Nutritional quality should affect growth and survival of nauplii and copepodid stages, as has been shown for Calanus helgolandicus/pacificus, where the ingestion of different diatom food species resulted in differing mortality rates and generation times (Paffenhöfer 1970). Similar findings were obtained by Carotenuto et al. (2002). The results of Koski et al. (1999) also revealed that food quality affects growth and development of calanoid copepods.

What are the mechanisms of transfer and accumulation of aldehydes and other toxic components, and their fate in growing copepods, as well as in eggs? There could be delayed effects, as has been shown for polychaete larvae cultured at very low aldehyde concentrations (0.0001 to $0.01 \mu \mathrm{g} \mathrm{l}^{-1}$ ). These had hatched normally, but expressed pronounced anatomical deformities when they metamorphosed to nechtochaete larvae (Lewis et al. 2004). This, again, could vary with copepod species, but also with their physiological state, as well as their particle environment.

It was pointed out that the methods of quantifying rates of ingestion, reproduction, mortality, etc., as well as egg viability, ought to be standardized; this would be essential for a sound comparison of results originating from different investigators working at different locations on different species.

\section{CHEMISTRY OF DIATOM DEFENSE}

\section{Main contributors: G. Pohnert and A. Fontana}

This section focuses on current and future strategies for the analyses of unsaturated aldehydes, the investigation of their biosynthetic origin and the regulation of their formation.

After the initial discovery of the inhibitory effect of unsaturated C10-aldehydes on the hatching success of copepods (Miralto et al. 1999), both mechanistic and methodological approaches were developed to gain an in-depth understanding of the 'defensive chemistry' of diatoms. During recent years, this has resulted in major progress towards the understanding of reactive aldehyde biosynthesis. Nevertheless, a detailed mechanistic and ecological understanding of the significance of diatom defense compared with the effects of overall food quality is yet to be achieved. Several different analytical approaches have been developed to detect unsaturated aldehydes in diatom cultures and in the natural environment (summarized in Table 1).

The data obtained to date from different diatom species and strains indicate that the formation of reactive aldehydes is not a universal property of all diatoms but is strongly variable among species and strains. For example, while Thalassiosira rotula, isolated from the Gulf of Naples, produces high amounts of $2 E, 4 Z, 7 Z$ -

Table 1. Extraction and detection methods for reactive aldehydes from marine and freshwater diatoms. NMR: nuclear magnetic resonance

\begin{tabular}{|c|c|c|c|c|}
\hline & $\begin{array}{l}\text { Wittig-based } \\
\text { Metabolically unknown } \\
\text { samples (single species } \\
\text { and phytoplankton) }\end{array}$ & $\begin{array}{l}\text { derivatization } \mathrm{a}^{\mathrm{a}, \mathrm{b}} \\
\text { Metabolically known } \\
\text { organisms }\end{array}$ & $\begin{array}{c}\text { Solid-phase } \\
\text { microextraction }\end{array}$ & HPLC-MS \\
\hline $\begin{array}{l}\text { Amount of wet } \\
\text { weight required }\end{array}$ & $2-5 \mathrm{~g}$ & $800-900 \mathrm{mg}$ & ca. $300 \mathrm{mg}$ & ca. $300 \mathrm{mg}$ \\
\hline Information & $\begin{array}{l}\text { Identification of } \\
\text { unknown metabolites } \\
\text { (assisted by NMR) }\end{array}$ & $\begin{array}{l}\text { Identification of } \\
\text { known metabolites } \\
\text { by GC-MS }\end{array}$ & $\begin{array}{l}\text { Identification of known } \\
\text { compounds with synthetic } \\
\text { standards using GC-MS } \\
\text { but difficult to quantify }\end{array}$ & $\begin{array}{l}\text { Identification of } \\
\text { known compounds } \\
\text { with synthetic } \\
\text { standards }\end{array}$ \\
\hline Time requirement & $5 \mathrm{~d}$ & $24 \mathrm{~h}$ & $3 \mathrm{~h}$ & $1 \mathrm{~h}$ \\
\hline Sample preparation & $\begin{array}{l}\text { Wounding/extraction/ } \\
\text { derivatization/ } \\
\text { chromatography }\end{array}$ & $\begin{array}{l}\text { Wounding/extraction/ } \\
\text { derivatization/ } \\
\text { chromatography }\end{array}$ & $\begin{array}{l}\text { Wounding/extraction/ } \\
\text { chromatography }\end{array}$ & $\begin{array}{l}\text { Wounding/ } \\
\text { chromatography }\end{array}$ \\
\hline Main advantages & $\begin{array}{c}\text { Derivatized samples } \\
\text { are stable } \\
\text { Field measurements } \\
\text { possible } \\
\text { Unambiguous } \\
\text { identification } \\
\text { No standards required }\end{array}$ & & $\begin{array}{c}\text { Fast and sensitive } \\
\text { Suitable for screenings of } \\
\text { different cultures }\end{array}$ & $\begin{array}{l}\text { Fast and sensitive } \\
\text { Reliable quantification } \\
\text { Identification of } \\
\text { polar oxylipins }\end{array}$ \\
\hline
\end{tabular}


decatrienal and 2E,4E,7Z-decatrienal and traces of 2E,4Z-decadienal, Skeletonema costatum from the Adriatic Sea produces the volatile C8 aldehydes $2 E, 4 Z$-octadienal and 2E,4Z,7-octatrienal as major metabolites. Recent studies have shown that different aldehydes are derived from polyunsatured C20 and C16 fatty acids (Pohnert 2000, d'Ippolito et al. 2002a,b, Pohnert et al. 2002), and that these compounds are produced not only by laboratory cultures but also by field-collected diatom species (A. Fontana \& G. Pohnert unpubl. data). Yet, seston from marine and freshwater habitats and cultured diatom species have been identified that do not produce any of these or related oxylipins (T. Wichard, A. Fontana \& G. Pohnert unpubl. data). This finding highlights the need for further screening of marine diatoms for their capability to synthesize unsaturated aldehydes. The laboratories in Jena (pohnert@ice.mpg.de), Napoli (afontana@ icmib.na.cnr.it; romano@szn.it) and Calgary (swatson@ ucalgary.ca) will perform these analyses and will give advice on sample preparation upon request.

Methods have been developed that provide tools for the investigation of the aldehyde production of diatom cultures or field samples and that can be used for a comparative screening of some of the major bloomforming diatoms. In this regard, it is of primary interest to analyze samples of phytoplankton collected during algal blooms under well-known marine environmental conditions. Assisted by parallel studies of the in situ dynamics of diatom and copepod populations, this work will clarify not only the presence of aldehydes in major marine algal blooms, but also the ecological role of these compounds under natural conditions. This will allow estimation of the distribution of the potentially inhibitory species in the natural environment. A recent comparative study of Thalassiosira rotula from the Gulf of Naples and coastal California showed that, despite being genetically closely related and morphologically nearly identical, the Naples isolate produced high amounts of antiproliferative aldehydes (same as above), while the California strain completely lacked the ability to form these compounds (Pohnert et al. 2002). These 2 strains could be used in further comparative studies for the evaluation of the effects of oxylipins compared to the overall effects of food quality.

A major task in the near future will be the development of chemical analytical methods that will allow us to investigate processes in the copepod gut and tissue, in order to evaluate the possible uptake and distribution of reactive aldehydes towards target molecules, cells and organs. Correlative studies have shown that the effect of externally added aldehydes is the same as that observed after ingestion of aldehyde-producing diatoms. However, the high concentrations of 1 to $2 \mu \mathrm{g}$ $\mathrm{ml}^{-1}$ decadienal required to induce an effect, and the unresolved question of local targeting of the metabolites in the copepods, do not allow the conclusion that these metabolites act directly and exclusively as defensive molecules to be made. Chemical methods, as well as bioassays and labeled probes, will be required in the future to bring a physiological understanding to this discussion. By using whole animals, it should be possible to investigate the distribution and location of reactive aldehydes after feeding. New strategies for the administration of reactive aldehydes with food will have to be developed. Whether this can be done, e.g. with microcapsules containing radioactive stable isotope-labeled samples of diatoms, will have to be established by collaboration among ecologists and analytical chemists.

Initial biosynthetic studies suggest that the production of these metabolites is triggered by mechanical damage (Pohnert 2000). After wounding, the release of eicosanoic fatty acids by a phospholipase $A_{2}$ is the first step of an enzymatic cascade involving a lipoxygenase and hydroperoxide lyase (Pohnert 2002). Studies of different diatom genera indicate that the biosynthesis of unsaturated aldehydes follows a similar pathway involving the same metabolic precursors and enzymes (Pohnert \& Boland 2002, d'Ippolito et al. 2003). However, different diatom species can produce unsaturated aldehydes with differing biological activities, as has been shown for Skeletonema costatum and Thalassiosira rotula, which produce C7, C8 and C10 aldehydes (d'Ippolito et al. 2002a,b).

Future work will lead to a more profound understanding of how these molecules are released into the environment during growth, senescence and the feeding process, and will give additional information on the cell targets of the molecules. The influence of environmental conditions on the ability of diatoms to form reactive metabolites will also be addressed. To date, no information is available as to whether external chemical signals, such as light, nutrients or temperature, affect the quantity of aldehydes produced per cell. Such information would lead to a better understanding of regional differences in the defensive potential of diatoms. The greatest challenge for future years will be the search for additional or alternative primary and secondary metabolites that can influence the reproductive success of copepods.

\section{NUTRITIONAL CHEMISTRY OF DIATOMS}

\section{Main contributors: D. Müller-Navarra and S. Jónasdóttir}

This section focuses on the differentiation of toxic effects from nutritive ones, i.e. compounds essential for copepod growth and development, with some sugges- 
tions for future research. The nutritional biology of marine copepods in general has recently been investigated by, e.g., Støttrup \& Jensen (1990), Jónasdóttir (1994), Ederington et al. (1995), Kleppel \& Burkart (1995), Pond et al. (1996), Guisande et al. (1999), and Klein Breteler et al. (1999). The focus of most of these studies was the effects of different algae on copepod performance. With regard to diatoms, monospecific diatom cultures have been shown to induce variable effects on copepod egg production and hatching (Jónasdóttir \& Kiørboe 1996, Ban et al. 1997, Paffenhöfer 2002), ranging from being an excellent food source to being detrimental for copepods. The main issue is that in many studies it is not clear whether, or under which conditions, reduced egg production and hatching rates are due to toxins (e.g. certain aldehydes) in diatoms or to a nutritional inadequacy of a diatom diet.

From general knowledge of nutrition, it has been established that a whole variety of biochemicals and minerals must be supplied by the food. As a result, there is a high probability that a monospecific algal diet is nutritionally unbalanced or even deficient in 1 or more substances, and hence of inferior quality to a multispecies food mixture. Thus, it is easier for a monospecific algal culture to be nutritionally inadequate than the natural mixed diet copepods encounter in the field.

Nutritional chemistry studies of zooplankton in general have mainly focused on the fatty acid composition of the food (e.g. Müller-Navarra 1995, Jónasdóttir \& Kiørboe 1996, von Elert 2002) and also, but to a lesser extent, on the amino acid composition (Kleppel \& Burkart 1995, Guisande et al. 1999) and, recently, sterols (von Elert et al. 2003, Hassett 2004). Although considerable advances have been made in our knowledge of the nature of the biochemicals that might be important for limiting zooplankton growth and egg production during the last decade (Støttrup \& Jensen 1990, Pond et al. 1996, Müller-Navarra et al. 2000, 2004, von Elert 2002, Becker \& Boersma 2003), it is not yet clear what might be missing from the pure monospecific diatom cultures that seem to be of suboptimal food quality. Recent studies suggest that linolenic acid (18:3(n-3), von Elert 2002 for Daphnia) or cholesterol (Hassett 2004) may be underrepresented in certain diatoms. In contrast, although eicosapentaenoic acid, 20:5(n-3), is 1 important semi-essential nutrient for zooplankton growth, the concentrations in diatoms are generally very high, so these compounds are not expected to be limiting. However, evidence from aquaculture research indicates that easily degradable fatty acids like 20:5(n-3) have to be offered in a protected and bioavailable form, and that too high a concentration can have a detrimental effect on the consumer (McEnvoy et al. 1995, Coutteau et al. 1997, Jüttner 2001).
Separating potential toxic effects from nutritional inadequacy or deficiency is a major challenge in the nutritional biology of zooplankton. The effect of toxic and nutritionally deficient diets can both result in similar or identical phenomena (i.e. exhibit the same phenotypic features) in copepod reproduction, hence they cannot be easily distinguished. Separating the effects may at times be impossible if both alternative causes are not addressed in the measurements of factors in the field and in the design of laboratory studies. One of the simplest ways to differentiate between toxicity and nutritional deficiency is by means of an indirect test in which a deficient nutritional substance should have an enhancement effect when added as a supplement to a copepod culture, whereas a toxic substance should have a deteriorating (impairing) effect on the consumer when added. In addition, measurements of ingestion to evaluate selection are necessary. The substances in question have to be chemically characterized, added in a bioavailable form (e.g. as microcapsules), and in a way which does not lead to dilution of the food solution to be tested.

Additionally, the biochemicals that are potentially the most limiting resources need to be identified so that the above-mentioned experimental approach can be applied. Recent research has revealed that a balance of various nutritional components is important to ensure a high nutritional value of phytoplankton for zooplankton (Kleppel 1993, Anderson \& Pond 2000). Even though, according to Liebig's law of the minimum, only 1 resource can be limiting at a time, a whole suite of essential nutrients should be required for somatic growth, egg production and hatching, because these 3 physiologically different production processes can have different nutritional requirements. In addition, because many nutritional substances can be stored in the copepod, experiments must ensure that these body reserves are depleted in the experimental animal before conclusions can be made about them being limiting under certain food conditions.

To fully understand the role of diatom quality in controlling copepod secondary production, only experiments and chemical analyses which integrate both toxic and nutritional aspects of food biochemistry will be successful in improving our understanding of the role of nutrition and toxicity in diatom-copepod interactions, and will resolve why some diatom species better support copepod population growth than others.

\section{FINAL CONSIDERATIONS FOR FUTURE RESEARCH}

Several suggestions for future research on diatomcopepod interactions have been presented in the previous sections. In addition, we want to complement 
these suggestions with some general thoughts, including methods, to be followed by specific proposals for future field and experimental efforts investigating diatom toxicity to copepods and nutritional value of diatoms, taking into account various recent observations on the interaction between copepods and their food organisms.

\section{General thoughts on methodology}

To obtain insights into the relationships between individual diatom species and the reproduction of individual copepod species, proven methodologies should be applied, following Ianora et al. $(1995,1996)$. The methods used for comparative purposes, including quantifying rates of ingestion, reproduction, mortality, egg viability, and chemical analyses, should be standardized. The approach of Nejstgaard et al. $(2001 \mathrm{a}, \mathrm{b})$ is recommended for obtaining information about the reproduction of individual copepod species feeding on natural food spectra. This could be complemented by the evolving methodology of Nejstgaard et al. (2003), which reveals the ingested food species via DNA markers in the gut contents. The latter methodology should also be used in conjunction with that of Ianora et al. (2004) when studying the extent to which juvenile stages are affected by ingested food taxa in situ. Stage-specific ingestion experiments should apply a single food taxon of proven 'good' quality as a control; focus should be on whether juvenile stages select for or against certain food types, and what biochemical compound may characterize such food types. A promising way to study these integrated effects on larval recruitment in natural plankton is by the use of mesocosms with minimally manipulated volumes (e.g. Nejstgaard et al. 2001b).

\section{Diatom toxicity to copepods}

Most in situ observations of deleterious effects were made when 1 or 2 species of diatoms dominated in coastal regions (Ianora \& Poulet 1993, Miralto et al. 1999, 2003, Ianora et al. 2004). To gain additional knowledge of the in situ effects of major diatom blooms consisting of 1 or 2 species, it may be useful to study other coastal regions and shallow shelves known for such or similar events over time. The following regions could be promising: (1) Mississippi River plume, where Turner \& Tester (1989) found that, at certain times, single diatom species such as Skeletonema costatum or Thalassiosira spp. comprised 79 to $85 \%$ of all cells; (2) the west coast of Scotland, where Marshall \& Orr (1930) reported a nearly monospecific bloom of $S$. costatum, which provided food for emerging populations of Calanus finmarchicus; (3) Campeche Banks in the Gulf of Mexico, with major diatom blooms (Belousov et al. 1966); and (4) coastal waters off south and western South Africa, with frequent diatom blooms due to upwelling (e.g. Pitcher 1988). In addition, certain offshore regions, such as the Arabian Sea during the SW monsoon (e.g. Smith 2001), and other wind-driven upwelling areas, e.g. the NW coast of the Iberian Peninsula, are known for pronounced diatom blooms. Contrasting with diatom toxic effects, there are also studies showing that diatoms have no or limited negative effects on the egg viability of various calanoid copepod species (Pond et al. 1996, Irigoien et al. 2002), or have only small effects (Miralto et al. 2003, summer). These studies were carried out when the diatom assemblage consisted of several species and concentrations were lower than those observed in early spring by Miralto et al. (2003). Observations range from 'near-catastrophic' events of diatom toxicity to copepod reproduction to cases in which the effects were far less noticeable, if at all (e.g. Laabir et al. 1995a). Unfortunately, the authors of most previous studies did not quantify the particle types actually ingested by the copepods, and no study correlating aldehyde production with ingested food is known. As it is possible that toxic diatoms are not ingested, the claims of the absence of negative effects caused by diatoms lack the basic information needed to substantiate the conclusions. It should be further emphasized that future in situ studies of food particle effects on zooplankton need to quantify both the types and amounts of food ingested (see Turner et al. 2001). This was achieved in the following time-series study: A series of 30 to $40 \mathrm{~d}$ mesocosm studies on the Norwegian west coast (J. C. Nejstgaard unpubl. data) showed a large variation in net production of copepods and other zooplankton between seasons and years. The mesocosms dominated by diatom blooms always supported a lower zooplankton net numerical and biomass increase than simultaneous mesocosms dominated by flagellates, despite the fact that both microplanktoncarbon biomass and copepod-carbon ingestion rates were similar or higher in the diatom blooms. Experimentally measured calanoid copepod egg production and hatching rates were also lower in diatomdominated waters. In these experiments, the diet of the calanoid copepods contained diatoms when present, but the diatoms were never the preferred food.

There could also be differences in the susceptibility of different calanoid copepod species to secondary metabolites produced by diatoms. Irigoien et al. (2002) observed relatively high hatching percentages of certain calanoid species, e.g. Calanus finmarchicus, in the St. Lawrence estuary, even when diatoms were pres- 
ent at high absolute and relative amounts (over $90 \%$ of the microplankton). However, they also reported low values for, e.g., Temora longicornis and Calanoides acutus, at concentrations and microplankton percentages similar to those above. It is hypothesized that not all species of calanoid copepods are sensitive to toxic substances produced by diatoms. Again, the uncertainty of ingested food particles prevents a thorough analysis and discussion when evaluating papers on this subject.

The main interest in this workshop was the effect of diatoms on copepods, especially under in situ conditions, when different taxa of phytoplankton and protozoans (mixotrophic and heterotrophic) occur. Protozoans generally make up only a small fraction of the unicellular plankton, yet they are preferentially ingested by copepods (e.g. Kleppel et al. 1991, Fessenden \& Cowles 1994) and, therefore, could directly and indirectly affect their reproduction, growth, and mortality. Also, calanoids are known to reduce their total ingestion significantly when numerous food particles are encountered, as compared to when only 1 food type is available (e.g. Paffenhöfer 1984). The reduced food intake, most likely due to food selection processes, could lessen a potential effect of diatoms, since egg viability has been shown to increase with decreasing concentrations of ingested diatom cells (Chaudron et al. 1996) and when copepods are offered mixed diets (Turner et al. 2001). Thus, one could hypothesize that many calanoid copepod species would not suffer negative diatom effects under field conditions when diatom abundances are high because of alternative choices and/or lower diatom ingestion. This could be seen as an evolutionary effect deriving from altering perceptions in response to the chemical signals provided. We are still at an early stage in determining the potential release of toxic compounds by numerous species and strains of diatoms from various parts of the oceans. Among major efforts for the near future, a priority should be the development of a catalogue or atlas of diatom species and their occurrence, so as to assess their potential toxic effect on copepods.

\section{Nutritional value of diatoms}

Most of the original studies of the nutritional quality of diatoms, as of algae in general, focused on their property to be easily ingested. In the last decade it became increasingly clear that their biochemical composition is also important for their quality as a food source for zooplankton including copepods.

Numerous studies of the fatty acid composition of diatoms have been conducted (e.g. Volkman et al. 1989, Viso \& Marty 1993), while studies of other nutri- tional components of diatoms, such as sterols and amino acids, are relatively few (but see Volkman et al. 1998 for sterols). Most studies of the specific nutritional needs of zooplankton have concentrated on the fatty acid composition of the food. While phytoplankton can synthesize a variety of so-called essential fatty acids ( $\omega-6$ and $\omega-3$ polyunsaturated fatty acids), amino acids and sterols, copepods cannot synthesize these compounds, and must obtain them from phytoplankton to support growth, reproduction and survival. While some calanoid species can lengthen and shorten fatty acids (Sargent \& Falk-Petersen 1988), we do not know if or how it benefits survival and growth.

A recent study by Hassett (2004) showed that addition of cholesterol to a diatom diet improved both egg production and hatching viability of Acartia hudsonica, whereas cholesterol supplementation did not affect egg production of Centropages hamatus. Cholesterol supplement of different diatom diets did not always result in production improvements. Thus, there appear to be species-specific differences in diatom sterols, as well as in copepod needs for dietary sterols. It is evident that the biochemical and, thus, the nutritional composition of phytoplankton changes as the availability of dissolved nutrients changes (Morris et al. 1983, Mayzaud et al. 1989). Feeding on diatoms at different growth phases results in different copepod egg production rates and egg viability (Jónasdóttir 1994, Jónasdóttir \& Kiørboe 1996). Future studies ought to simultaneously focus on more than 1 type of nutrient in order to understand the different phases of growth.

Studies of the mortality rates of developing copepod populations offered different species of phytoplankton at similar and also at different concentrations have revealed effects of food species as well as of food concentration (Paffenhöfer 1970, Carotenuto et al. 2002 and references therein). Females of certain copepod species that had been reared at high diatom concentrations were rather sluggish when escaping from hydrodynamic signals after their final molt, as compared to specimens reared on diatoms at 1 order of magnitude lower concentration (G. A. Paffenhöfer unpubl. obs.). The females receiving a higher food concentration also experienced higher and earlier mortality. No information on the effects of satiation on copepod performance appears to exist. There is also very little information on the effects of the feeding history of early juvenile stages, as well as the feeding history of parent copepods, on their present performance. By comparison, a study of several generations of humans revealed that grandparents' eating habits can affect the health of generations twice removed: 'Grandchildren of well-fed grandfathers were 4 times as likely to die from diabetes' (Kaati et al. 2002). These 
effects were considered to be due to eating behavior, and not genetics.

Quantification of molecular compounds in the gut (Nejstgaard et al. 2003) may provide insight into the recent feeding history of a single copepod, especially in situ. The biochemical composition of the body of a copepod (Lee et al. 1971) could inform us about the feeding history on longer time scales. From those data, in relation to the food types available, we may be able to determine a copepod species' approach to a 'healthy diet'. Future nutritional studies of diatoms should include looking for biochemical differences between diatom species and changes in composition with age, to improve our insight into nutritional effects. Experimental studies should include several groups of essential nutrients. A considerable amount of information is available on the biochemical composition of phytoplankton, and numerous studies have been conducted on reproductive and behavioral responses of copepods to different types of food. This published information is seen as a foundation to be applied to future studies of the nutritional effects of diatoms and other food organisms on zooplankton.

\section{CONCLUSIONS}

The workshop was an attempt to assess the present status of research into diatom-copepod interactions, with emphasis on the effect of diatoms on copepod reproduction. We also considered the potential nutritional effects of food on growth and survival. It has to be kept in mind that the following sequence occurs in nature: a copepod encounters a wide range of potential food organisms (a spectrum), which is followed by food selection, then by the effects of the food on the copepod (whether as nauplius, copepodid stage, or adult male or female, or even through the following generations). All feeding stages are involved, and potential effects may not be highly visible or pronounced, as in some of the above-mentioned results concerning the effects of toxic diatoms on egg viability. We are at an early stage and need to chart out research plans to address the open questions and hypotheses, including those emerging as we proceed. It is clear that good communication among the research teams involved in diatom-copepod interactions will enhance progress. It is our hope that such communication will continue, reflecting the positive and collaborative attitude of the participants of our workshop.

Acknowledgements. We wish to thank the Stazione Zoologica Anton Dohrn for their generous financial support which provided traveling and logistics for many of the participants of this colloquium. We also thank the Benthos Laboratory of the Stazione Zoologica Anton Dohrn for hosting the meeting.

\section{LITERATURE CITED}

Adolph S, Poulet SA, Pohnert G (2003) Synthesis and biological activity of $\alpha, \beta, \gamma, \delta$-unsaturated aldehydes from diatoms. Tetrahedron 59:3003-3008

Anderson TR, Pond DW (2000) Stoichiometric theory extended to micronutrients: comparison of the roles of essential fatty acids, carbon and nitrogen in the nutrition of marine copepods. Limnol Oceanogr 45:1162-1167

Armbrust V, Berges JA, Bowler C, Green BR and 42 others (2004) The genome of the diatom Thalassiosira pseudonana: ecology, evolution and metabolism. Science 306: $79-86$

Azam F, Fenchel T, Field JG, Gray JS, Meyer-Reil LA, Thingstad F (1983) The ecological role of water-column microbes in the sea. Mar Ecol Prog Ser 10:257-263

Ban S, Burns C, Castel J, Chaudron Y and 19 others (1997) The paradox of diatom-copepod interactions. Mar Ecol Prog Ser 157:287-293

Ban SH, Lee HW, Shinada A, Toda T (2000) In situ egg production and hatching success of the marine copepod Pseudocalanus newmani in Funka Bay and adjacent waters off southwestern Hokkaido, Japan: associated to diatom bloom. J Plankton Res 22:907-922

Bates SS, Worms J, Smith JC (1993) Effects of ammonium and nitrate on growth and domoic acid production by Nitzschia pungens in batch culture. Can J Fish Aquat Sci 50:1248-1254

Becker C, Boersma M (2003) Resource quality effects on life histories of Daphnia. Limnol Oceanogr 48:700-706

Belousov IM, Ivanov YA, Pasternak SA, Rass TS, Rossov VV (1966) Oceanographic research by the Soviet-Cuban marine expedition. Oceanology (USSR) 6:312-320

Bolch CJ, Negri AP, Blackburn SI, Green DH (2002) Life cycle variation in PST content and cell toxicity in PST-producing dinoflagellates. In: Garcés Z, Zingone A, Montresor M, Reguera B, Dale B (eds) LIFEHAB life histories of microalgal species causing harmful algal blooms. Research in Enclosed Seas Series. European Commission, Science, Research, Development, Brussels, p 37-52

Calbet A, Landry MR (2004) Phytoplankton growth, microzooplankton grazing, and carbon cycling in marine systems. Limnol Oceanogr 49:51-57

Caldwell GS, Olive PJW, Bentley MG (2002) Inhibition of embryonic development and fertilization in broadcast spawning invertebrates by water soluble diatom extracts and the diatom toxin 2,trans, 4,trans decadienal. Aquat Toxicol 60:123-137

Carotenuto Y, Ianora A, Buttino I, Romano G, Miralto A (2002) Is postembryonic development in the copepod Temora stylifera negatively affected by diatom diets? J Exp Mar Biol Ecol 276:49-66

Casotti R, Mazza S, Ianora A, Miralto A (2001) Growth and cell cycle progression in the diatom Thalassiosira weissflogii is inhibited by the diatom aldehyde 2-trans-4-transdecadienal. ASLO Aquatic Sciences 2001 Meeting, Special Session 22-Strategies to reduce mortality in marine and freshwater phytoplankton, Albuquerque, 24-27 October 2001, European Commission Research Directorate General

Casotti R, Mazza S, Brunet C, Vantrepotte V, Ianora A, Miralto A (2005) Growth inhibition and toxicity of the diatom aldehyde 2-trans-4-trans decadienal on Thalassiosira weissflogii (Bacillariophyceae). J Phycol 41 (in press)

Chaudron Y, Poulet SA, Laabir M, Ianora A, Miralto A (1996) Is hatching success of copepod eggs diatom densitydependent? Mar Ecol Prog Ser 144:185-193 
Clarke GL (1939) The relation between diatoms and copepods as a factor in the productivity of the sea. Q Rev Biol 14:60-64

Coutteau P, Geurden I, Camara MR, Bergot P, Sorgeloos P (1997) Review on the dietary effects of phospholipids in fish and crustacean larviculture. Aquaculture 155:149-164

Cushing DH (1989) A difference in structure between ecosystems in strongly stratified waters and in those that are only weakly stratified. J Plankton Res 11:1-13

Dakin WJ (1908) Notes on the alimentary canal and food of the copepods. Int Rev Gesamten Hydrobiol Hydrogr 1: $772-782$

d'Ippolito G, Iadicicco O, Romano G, Fontana A (2002a) Detection of short-chain aldehydes in marine organisms: the diatom Thalassiosira rotula. Tetrahedron Lett 43: $6137-6140$

d'Ippolito G, Romano G, Iadicicco O, Miralto A, Ianora A, Cimino G, Fontana A (2002b) New birth-control aldehydes from the marine diatom Skeletonema costatum. Tetrahedron Lett 43:6133-6136.

d'Ippolito G, Romano G, Caruso T, Spinella A, Cimino G, Fontana A (2003) Production of octadienal in the marine diatom Skeletonema costatum. Org Lett 5:885-887

Ederington M, McManus G, Harvey H (1995) Trophic transfer of fatty acids, sterols, and triterpenoid alcohol between bacteria, a ciliate, and the copepod Acartia tonsa. Limnol Oceanogr 40:860-867

Fessenden L, Cowles TJ (1994) Copepod predation on phagotrophic ciliates in Oregon coastal waters. Mar Ecol Prog Ser 107:103-111

Frost BW (1987) Grazing control of phytoplankton stock in the open subarctic Pacific Ocean: a model assessing the role of mesozooplankton, particularly the large calanoid copepods Neocalanus spp. Mar Ecol Prog Ser 39:49-68

Greve W, Parsons TR (1977) Photosynthesis and fish production: hypothetical effects of climatic change and pollution. Helgol Wiss Meeresunters 30:666-672

Guisande C, Harris R (1995) Effect of total organic content of eggs on hatching success and naupliar survival in the copepod Calanus helgolandicus. Limnol Oceanogr 40: 476-482

Guisande C, Maneiro I, Riveiro I (1999) Homeostasis in the essential amino acid composition of the marine copepod Euterpina acutifrons. Limnol Oceanogr 44:691-696

Guisande C, Riveiro I, Maneiro I (2000) Comparisons among the amino acid composition of females, eggs and food to determine the relative importance of food quantity and food quality to copepod reproduction. Mar Ecol Prog Ser 202:135-142

Hassett RP (2004) Supplementation of a diatom diet with cholesterol can enhance copepod egg production rates. Limnol Oceanogr 49:488-494

Ianora A, Poulet SA (1993) Egg viability in the copepod Temora stylifera. Limnol Oceanogr 38:1615-1626

Ianora A, Poulet SA, Miralto A (1995) A comparative study of the inhibitory effect of diatoms on the reproductive biology of the copepod Temora stylifera. Mar Biol 121:533-539

Ianora A, Poulet SA, Miralto A, Grottoli R (1996) The diatom Thalassiosira rotula affects reproductive success in the copepod Acartia clausi. Mar Biol 125:279-286

Ianora A, Poulet SA, Miralto A (2003) The effects of diatoms on copepod reproduction: a review. Phycologia 42:351-363

Ianora A, Miralto A, Poulet SA, Carotenuto Y and 8 others (2004) Aldehyde suppression of copepod recruitment in blooms of a ubiquitous planktonic diatom. Nature 429:403-407

Imada N, Kobayashi K, Tahara K, Oshima Y (1991) Production of an autoinhibitor by Skeletonema costatum and its effect on the growth of other phytoplankton. Nippon Suisan Gakkaishi 57:2285-2290

Irigoien X, Head RN, Harris RP, Cummings D, Harbour D, Meyer-Harms B (2000a) Feeding selectivity and egg production of Calanus helgolandicus in the English Channel. Limnol Oceanogr 45:44-54

Irigoien X, Harris RP, Head RN, Harbour D (2000b) The influence of diatom abundance on the egg production rate of Calanus helgolandicus in the English Channel. Limnol Oceanogr 45:1433-1439

Irigoien $\mathrm{X}$, Harris RP, Verheye HM, Joly $\mathrm{P}$ and 14 others (2002) Copepod hatching success in marine ecosystems with high diatom concentrations. Nature 419:387-389

Jónasdóttir SH (1994) Effects of food quality on the reproductive success of Acartia tonsa and Acartia hudsonica: laboratory observations. Mar Biol 121:67-81

Jónasdóttir SH, Kiørboe T (1996) Copepod recruitment and food composition: do diatoms affect hatching success? Mar Biol 125:743-750

Jónasdóttir SH, Kiørboe T, Tang KW, St. John M, Visser AW, Saiz E, Dam HG (1998) Role of diatoms in copepod production: good, harmless or toxic? Mar Ecol Prog Ser 172: 305-308

Jüttner F (2001) Liberation of 5,8,11,14,17-eicosapentaenoic acid and other polyunsaturated fatty acids from lipids as a grazer defense reaction in epilithic diatom biofilms. J Phycol 37:744-755

Kaati G, Bygren LO, Edvinsson S (2002) Cardiovascular and diabetes mortality determined by nutrition during parents' and grandparents' slow growth period. Eur J Hum Genet 10:682-688

Klein Breteler W, Schogt N, Baas M, Schouten S, Kraay G (1999) Trophic upgrading of food quality by protozoans enhancing copepod growth: role of essential lipids. Mar Biol 135:191-198

Kleppel GS (1993) On the diets of calanoid copepods. Mar Ecol Prog Ser 99:183-195

Kleppel GS, Burkart C (1995) Egg production and the nutritional environment of Acartia tonsa: the role of food quality in copepod nutrition. ICES J Mar Sci 52:297-304

Kleppel GS, Holiday DV, Pieper RE (1991) Trophic interactions between copepods and icroplankton: a question about the role of diatoms. Limnol Oceanogr 36:172-178

Kleppel GS, Burkhart CA, Houchin L (1998a) Nutrition and the regulation of egg production in the calanoid copepod Acartia tonsa. Limnol Oceanogr 43:1000-1007

Kleppel GS, Burkhart CA, Houchin L, Tomas C (1998b) Egg production of the copepod Acartia tonsa in Florida Bay during summer. 1. The roles of environment and diet. Estuaries 21:328-339

Koski M, Klein Breteler W, Schogt N (1998) Effect of food quality on rate of growth and development of the pelagic copepod Pseudocalanus elongatus (Copepoda, Calanoida). Mar Ecol Prog Ser 170:169-187

Koski M, Engström J, Viitasalo M (1999) Reproduction and survival of the calanoid copepod Eurytemora affinis fed with toxic and non-toxic cyanobacteria. Mar Ecol Prog Ser 186:187-197

Laabir M, Poulet SA, Ianora A, Miralto A, Cueff A (1995a) Reproductive response of Calanus helgolandicus. II. In situ inhibition of embryonic development. Mar Ecol Prog Ser 129:97-105

Laabir M, Poulet SA, Ianora A (1995b) Measuring production and viability of eggs in Calanus helgolandicus. J Plankton Res 17:1125-1142

Laabir M, Poulet SA, Harris RP, Cueff A, Head RN, Ianora A (1998) Comparative study of the reproduction of Calanus 
helgolandicus in well-mixed and seasonally stratified coastal waters of the western English Channel. J Plankton Res 20:407-421

Lacoste A, Poulet SA, Cueff A, Kattner G, Ianora A, Laabir M (2001) New evidence of the copepod maternal food effects on reproduction. J Exp Mar Biol Ecol 259:85-107

Lee HW, Ban S, And Y, Ota T, Ikeda T (1999) Deleterious effects of diatom diets on egg production and hatching success in the marine copepod Pseudocalanus newmani. Plankton Biol Ecol 46:104-112

Lee RF, Nevenzel JC, Paffenhöfer GA (1971) Importance of wax esters and other lipids in the marine food chain: phytoplankton and copepods. Mar Biol 9:99-108

Lewis C, Caldwell GS, Bentley MG, Olive PJW (2004) Effects of a bioactive diatom-derived aldehyde on developmental stability in Nereis virens larvae: an analysis using fluctuating asymmetry. J Exp Mar Biol Ecol 304:1-16

Marshall SM (1924) The food of Calanus finmarchicus during 1923. J Mar Biol Assoc UK 13:473-479

Marshall SM (1973) Respiration and feeding in copepods. Adv Mar Biol 11:57-120

Marshall SM, Orr AP (1930) A study of the spring diatom increase in Loch Striven. J Mar Biol Assoc UK 16:853-878

Mauchline J (1998) The biology of calanoid copepods. Adv Mar Biol 33:1-710

Mayzaud P, Chanut JP, Ackman RG (1989) Seasonal changes of the biochemical composition of marine particulate matter with special reference to fatty acids and sterols. Mar Ecol Prog Ser 56:189-204

McEnvoy, LA, Navarro JC, Bell JG, Sargent JR (1995) Autoxidation of oil emulsions during the Artemia enrichment process. Aquaculture 134:101-112

McClintock JB, Baker BJ (eds) (2001) Marine chemical ecology. CRC Press, Boca Raton, FL

Mills EL (1989) Biological oceanography: an early history, 1870-1960. Cornell University Press, Ithaca, NY

Miralto A, Barone G, Romano G, Poulet SA and 7 others (1999) The insidious effect of diatoms on copepod reproduction. Nature 402:173-176

Miralto A, Guglielmo L, Zagami G, Buttino I, Granata A, Ianora A (2003) Inhibition of population growth in the copepods Acartia clausi and Calanus helgolandicus during diatom blooms. Mar Ecol Prog Ser 254:253-268

Morris RJ, McCartney MJ, Robinson GA (1983) Studies of a spring diatom bloom in an enclosed experimental ecosystem. I. Biochemical changes in relation to the nutrient chemistry of water. J Exp Mar Biol Ecol 70:249-262

Müller-Navarra DC (1995) Evidence that a highly unsaturated fatty acid limits Daphnia growth in nature. Arch Hydrobiol 132:297-307

Müller-Navarra DC, Brett MT, Liston AM, Goldman CR (2000) A highly unsaturated fatty acid predicts carbon transfer between primary producers and consumers. Nature 403:74-77

Müller-Navarra D, Brett MT, Park S, Chandra S, Ballantyne AP, Zorit E, Goldman CR (2004) Unsaturated fatty acid content in seston and tropho-dynamic coupling in lakes. Nature 427:69-72

Nejstgaard JC, Naustvoll LJ, Sazhin A (2001a) Correcting for underestimation of microzooplankton grazing in bottle incubation experiments with mesozooplankton. Mar Ecol Prog Ser 221:59-75

Nejstgaard JC, Hygum BH, Naustvoll LJ, Båmstedt U (2001b) Zooplankton growth, diet and reproductive success compared in simultaneous diatom- and flagellate-microzooplankton-dominated plankton blooms. Mar Ecol Prog Ser 221:77-91
Nejstgaard JC, Frischer ME, Raule CL, Gruebel R, Kohlberg KE, Verity PG (2003) Molecular detection of algal prey in copepod guts and fecal pellets. Limnol Oceanogr Methods $1: 29-38$

Nelson DM, Tréguer P, Brzezinski MA, Leynaert A, Quéguiner B (1995) Production and dissolution of biogenic silica in the ocean: revised global estimates, comparison with regional data and relationship to biogenic sedimentation. Global Biogeochem Cycles 9:359-372

Ohman MD, Runge JA (1994) Sustained fecundity when phytoplankton resources are in short supply: omnivory by Calanus finmarchicus in the Gulf of St. Lawrence. Limnol Oceanogr 39:21-36

Paffenhöfer GA (1970) Cultivation of Calanus helgolandicus under controlled conditions. Helgol Wiss Meeresunters 20:346-359

Paffenhöfer GA (1984) Food ingestion by the marine planktonic copepod Paracalanus in relation to abundance and size distribution of food. Mar Biol 80:323-333

Paffenhöfer GA (2002) An assessment of the effects of diatoms on planktonic copepods. Mar Ecol Prog Ser 227:305-310

Pinto CSC, Souza-Santos LP, Santos PJP (2001) Development and population dynamics of Tisbe biminiensis (Copepoda:Harpacticoida) reared on different diets. Aquaculture 198:253-267

Pitcher GC (1988) Mesoscale heterogeneities of the phytoplankton distribution in St. Helena Bay, South Africa, following an upwelling event. S Afr J Mar Sci 7:9-23

Pohnert G (2000) Wound-activated chemical defense in unicellular planktonic algae. Angew Chem Int Ed 39: 4352-4354

Pohnert G (2002) Phospholipase $\mathrm{A}_{2}$ activity triggers the wound-activated chemical defense in the diatom Thalassiosira rotula. Plant Physiol 129:103-111

Pohnert G, Boland W (2002) The oxylipin chemistry of attraction and defense in brown algae and diatoms. Nat Prod Rep 19:108-122

Pohnert G, Lumineau O, Cueff A, Adolph S, Cordevant C, Lange M, Poulet S (2002) Are volatile unsaturated aldehydes from diatoms the main line of chemical defence against copepods? Mar Ecol Prog Ser 245:33-45

Pond D, Harris R, Head R, Harbour D (1996) Environmental and nutritional factors determining seasonal variability in the fecundity and egg viability of Calanus helgolandicus in coastal waters off Plymouth, UK. Mar Ecol Prog Ser 143: $45-63$

Poulet SA, Laabir M, Ianora A, Miralto A (1995) Reproductive response of Calanus helgolandicus. I. Abnormal embryonic and naupliar development. Mar Ecol Prog Ser 129: 85-95

Romano G, Russo GL, Buttino I, Ianora A, Miralto A (2003) A marine diatom-derived aldehyde induces apoptosis in copepod and sea urchin embryos. J Exp Biol 206:3487-3494

Rosenthal GA, Berenbaum MR (eds) (1991) Herbivores: their interactions with secondary plant metabolites, Vol 1. The chemical participants. Academic Press, San Diego, CA

Runge JA, de Lafontaine Y (1996) Characterization of a pelagic food web in the northern Gulf of St. Lawrence: the larval redfish-Calanus-microplankton interaction. Fish Oceanogr 5:21-37

Ryther JH (1969) Photosynthesis and fish production in the sea. Science 166:72-76

Sargent JR, Falk-Petersen S (1988) The lipid biochemistry of Calanus. Hydrobiologia 167/168:101-114

Schmidt LE, Hansen PJ (2001) Allelopathy in the prymnesiophyte Chrysochromulina polylepis: effect of cell concentration, growth phase and pH. Mar Ecol Prog Ser 216:67-81 
Schmidt K, Jónasdóttir SH (1997) Nutritional quality of two cyanobacteria: how rich is 'poor' food? Mar Ecol Prog Ser 151:1-10

Sherr EB, Sherr BF, Paffenhöfer GA (1986) Phagotrophic protozoa as food for metazoans: a 'missing' trophic link in marine pelgaic food webs? Mar Microb Food Webs 1:61-80

Smith SL (2001) Understanding the Arabian Sea: reflections on the 1994-1996 Arabian Sea expedition. Deep-Sea Res II 48:1385-1402

Starr M, Runge JA, Therrialt JC (1999) Effects of diatom diets on the reproduction of the planktonic copepod Calanus finmarchicus. Sarsia 84:379-389

Stoecker DK, Capuzzo JM (1990) Predation on protozoa: its importance to zooplankton. J Plankton Res 12:891-908

Støttrup J, Jensen J (1990) Influence of algal diet on feeding and egg-production of the calanoid copepod Acartia tonsa Dana. J Exp Mar Biol Ecol 141:87-105

Tang KW, Dam HG, Feinberg LR (1998) The relative importance of egg production rate, hatching success, hatching duration and egg sinking in population recruitment of two species of marine copepods. J Plankton Res 20:1971-1987

Turner JT, Roff JC (1993) Trophic levels and trophospecies in marine plankton: lessons from the microbial food web. Mar Microb Food Webs 7:225-248

Turner JT, Tester PA (1989) Zooplankton feeding ecology: nonselective grazing by the copepods Acartia tonsa Dana, Centropages velificatus de Oliveira, and Eucalanus pileatus Giesbrecht in the plume of the Mississippi River. J Exp Mar Bio Ecol 126:21-43

Turner JT, Ianora A, Miralto A, Laabir M, Esposito F (2001) Decoupling of copepod grazing rates, fecundity and egghatching success on mixed and alternating diatom and dinoflagellate diets. Mar Ecol Prog Ser 220:187-199

Verity PG, Paffenhöfer GA (1996) On assessment of prey ingestion by copepods. J Plankton Res 18:1767-1779

Viso AC, Marty JC (1993) Fatty acids from 28 marine microalgae. Phytochemistry 34:1521-1533

Editorial responsibility: Otto Kinne (Editor-in-Chief), Oldendorf/Luhe, Germany
Volkman JK, Jeffrey SW, Rogers GI, Nichols PD, Garland CD (1989) Fatty acids and lipid composition of 10 microalgae used in mariculture. J Exp Mar Biol Ecol 128: $219-240$

Volkman JK, Barrett SM, Blackburn SI, Mansour MP, Sikes EL, Gelin F (1998) Microalgal biomarkers: a review of recent research developments. Org Geochem 29: 1163-1179

von Elert E (2002) Determination of limiting polyunsaturated fatty acids in Daphnia galeata using a new method to enrich food algae with single fatty acids. Limnol Oceanogr 47:1764-1773.

von Elert E, Martin-Creutzberg D, Le-Coz JR (2003) Absence of sterols constrains carbon transfer between cyanobacteria and a freshwater herbivore (Daphnia galeata). Proc R Soc Lond B 270:1209-1214

Watson SB (2003) Cyanobacterial and eukaryotic algal odour compounds: signals or by products? A review of their biological activity. Hydrobiologia 42:332-350

Watson SB, Satchwill T (2003) Chrysophyte odour production: resource-mediated changes at the cell and population levels. Phycologia 42:393-405

Watson SB, Brownlee B, Satchwill T, McCauley E (1999) The use of solid phase microextraction (SPME) to monitor for major organoleptic compounds produced by chrysophytes in surface waters. Water Sci Technol 40:251-256

Wiegman S, Termeer JAG, Verheul T, Kraak MHS, De Voogt P, Laane RWPM, Admiraal W (2002) UV absorbancedependent toxicity of acridine to the marine diatom Phaeodactylum tricornutum. Environ Sci Technol 36: 908-913

Wolfe GV, Steinke M, Kirst M (1997) Grazing-activated chemical defence in a unicellular marine alga. Nature 387 : 894-897

Yoshida T, Jones LE, Ellner SP, Fussmann GF, Hairston NG Jr (2003) Rapid evolution drives ecological dynamics in a predator-prey system. Nature 424:303-306

Submitted: January 26, 2004; Accepted: September 7, 2004

Proofs received from author(s): January 19, 2005 